\title{
PENGEMBANGAN OFF JOB TRAINING SPESIALIS PERBAIKAN BOOM EXCAVATOR DENGAN PENGELASAN GMAW DI PT THIESS
}

\author{
Galih Chandra Pratama ${ }^{1}$, Wagiran ${ }^{2}$, Soeprapto Rachmad Said ${ }^{3}$ \\ ${ }^{1,2,3}$ Program Studi Pendidikan Teknik Mesin Fakultas Teknik UNY \\ artha_chandra@yahoo.co.id
}

\begin{abstract}
The purpose of this study was to determine the characteristics and effectiveness of off-the-job training for repairing damaged boom excavator with GMAW welding processes in XXI Welder group at PT. Thiess. The research methods being used were Research and Development. Data were collected using observation, interview, test and questionnaire. The object of this study is class group, which is the apprentice group XXI Welder at PT. Thiess with 10 trainees as respondents. Data were analyzed using comparative statistics techniques with a non-parametric test. Data were compared based on the results obtained from the research instruments. The result shows the characteristics of learning off-the-job training, which are: learning is done based on case studies found in the workplace; the training participants is limited; the learning methods is group teaching, in which the learners are active with simulation methods. The effectiveness of learning offthe-job training were analyzed using non-parametric Wilcoxon comparative tests. From the pre-test and posttest data it was obtained the p-value of 0.007 , so that $0.007<0.05$ therefore reject $H_{0}$. It shows that there are differences in the pre-test and post-test result of the learners.
\end{abstract}

Keywords : research and development, off the job training, boom excavator, wilcoxon non-parametric test

\begin{abstract}
ABSTRAK
Tujuan penelitian ini adalah untuk mengetahui karakteristik dan efektivitas pembelajaran off job training untuk perbaikan hasil lasan pada boom excavator yang mengalami kerusakan dengan proses pengelasan $G M A W$ pada peserta apprentice program group XXI Welder di PT Thiess. Penelitian ini menggunakan metode research and development. Pengumpulan data menggunakan metode observasi, wawancara, tes dan angket. Objek penelitian ini adalah peserta didik Apprentice Program bidang Welder group XXI PT Thiess dengan jumlah responden 10 orang. Teknik analisis data berupa statistik komparatif menggunakan uji non-parametrik, data yang ada dibandingkan berdasarkan hasil yang diperoleh dari instrumen penelitian. Hasil penelitian menunjukkan bahwa karakteristik pembelajaran off job training yaitu peserta terbatas dengan pembelajaran berupa group teaching dimana pesera didik bersifat aktif dengan metode simulasi. Efektifitas pembelajaran berdasarkan uji non-parametrik Wilcoxon menunjukkan bahwa nilai untuk data pre-test \& post-test peserta didik $p$-value sebesar 0.007 sehingga $0,007<0,05$ tolak $\mathrm{H}_{0}$ yang menyatakan bahwa ada perbedaan nilai pre-test dan post-test peserta didik pada pengembangan pembelajaran off job training perbaikan hasil lasan pada boom excavator.
\end{abstract}

Kata kunci: Off Job Training, Boom Excavator, pengelasan GMAW

\section{PENDAHULUAN}

Era persaingan global yang dihadapi saat ini menuntut sumber daya manusia yang berkualitas untuk siap menjadi tenaga kerja yang profesional. SMK memiliki tujuan utama untuk menyiapkan kesiapan kerja siswa lulusannya, yaitu agar siswanya dapat bekerja sesuai dengan bidang keahliannya dan dapat meraih kesuksesan. Undang-Undang No. 20 Tahun 2003 tentang Sistem Pendidikan Nasional menjelaskan bahwa pendidikan kejuruan merupakan pendidikan menengah yang mempersiapkan peserta didik terutama untuk bekerja dalam bidang tertentu. Tenaga kerja yang dihasilkan diharapkan memiliki pengetahuan, keterampilan, dan sikap kerja yang sesuai dengan kebutuhan industri. Beberapa upaya perbaikan mutu telah dilaksanakan oleh pemerintah, akan tetapi peran SMK dalam menyiapkan tenaga kerja profesional masih kurang sesuai dengan kebutuhan pihak industri. Hal ini terlihat dari tingkat mutu dan kesiapan kerja siswa SMK 
yang dirasa masih kurang terpenuhi untuk bekerja mandiri di industri.

Akhmad Sudrajat (2014) menjelaskan bahwa setiap lulusan SMK disiapkan untuk menjadi sumber daya manusia yang siap pakai. Hal ini menunjukkan bahwa setelah menyelesaikan program pendidikan, para lulusan SMK diharapkan dapat menerapkan ilmunya di dunia kerja. Kenyataan menunjukkan bahwa industri atau perusahaan sebagai pengguna lulusan SMK belum sepenuhnya dapat mempekerjakan secara langsung para lulusan SMK tersebut karena tingkat kompetensi yang dimilikinya belum sesuai dengan persyaratan yang diharapkan dan ditetapkan oleh industri.

Upaya yang dapat ditempuh untuk meningkatkan kompetensi lulusan SMK tersebut, maka pihak industri memberikan solusi dengan cara program pemagangan kepada lulusan SMK sebelum terjun langsung di lapangan. Salah satu perusahaan yang melaksanakan program tersebut adalah PT Thiess Contractor Indonesia yang beralamat di Jalan Mulawarman No 1, Kecamatan Manggar, Balikpapan, Kalimantan Timur. Bidang kejuruan yang dilatihkan pada program pemagangan di PT Thiess adalah bidang kejuruan permesinan dan otomotif (mekanik), kejuruan elektrik otomotif (auto elektric) dan kejuruan fabrikasi (pengelasan). Pemilihan bidang kejuruan ini disesuaikan dengan lingkup kerja perusahaan yang bergerak diranah pertambangan (Dody Arifandi, 2012).

Hasil wawancara langsung terhadap salah seorang supervisor workshop service menyatakan bahwa para apprentice welder yang melakukan on job training masih belum mampu untuk melakukan inspeksi mendetail terhadap kerusakan yang terjadi akibat dampak dari fatigue pada alat berat baik shovel maupun backhoe. Balaster Banjarnahor, seorang spesialist welding trainer, mengatakan: "Belum ada prosedur perbaikan secara spesifik. Oleh karena itu perlu dilakukan pendekatan bagaimana cara melakukan perawatan perbaikan khususnya pada komponen boom di unit excavator tersebut". Proses pemecahan masalah ini dapat dibuat dengan mengetahui spesifikasi unit, jenis material yang digunakan mengacu pada ASTM 30, ASTM 36 dan ASTM 90-60 serta menganalisa proses perbaikan yang akan dilakukan. Langkah selanjutnya adalah membuat prosedur perbaikan dan tahapan terakhir adalah memberikan pelatihan kepada para peserta didik yang akan dibentuk kompetensinya menjadi spesialis perbaikan boom excavator dengan proses pengelasan GMAW.

Berdasarkan uraian di atas, maka sangat penting untuk dilakukan penelitian tentang pengembangan model off job training untuk menjadi spesialis perbaikan boom excavator dengan proses pengelasan GMAW pada Apprentice group XXI welder di PT Thiess.

\section{METODE}

Penelitian ini merupakan penelitian dan pengembangan (Research and Development). Sugiyono, (2013: 297) menjelaskan bahwa metode Research and Development adalah metode penelitian yang digunakan untuk menghasilkan produk tertentu, dan menguji keefektifan produk tersebut. Model yang digunakan adalah model ADDIE. Benny A. Pribadi (2009:125) pengembangan model ADDIE meliputi lima langkah, yaitu 1) Analysis (Analisis), 2) Design (Desain), 3) Development or Production (Pengembangan atau Produk), 4) Implemantation or Delivery (Implementasi atau Penyampaian), 5) Evaluation (Evaluasi). Pengembangan model ADDIE menghasilkan sebuah produk berupa training package. Metode pengumpulan data yang digunakan berupa observasi, wawancara, tes tulis dan angket pendukung. Analisis data dalam penelitian ini dilakukan secara komparatif menggunakan uji non-parametrik test. Subjek yang digunakan dalam penelitian ini adalah peserta didik apprentice welder group XXI PT. Thiess dengan jumlah sebanyak 10 orang peserta.

Tahapan penelitian yang dilakukan adalah meliputi observasi di area kerja secara 
menyeluruh, mendesain training package berdasarkan hasil observasi berupa kurikulum pelatihan, mengembangkan training package, mengimplementasikan pelatihan dan melakukan evaluasi hasil dengan menggunakan data yang diperoleh selama pelatihan berupa nilai pre-test dan post-test kemudian dianalisa menggunakan uji statistik non-paramtrik (Sugiyono, 2013:134-142).

Teknik pengumpulan data dilakukan melalui angket yang berfungsi untuk mengetahui kelayakan training package menggunakan lembar checklist dengan skala Likert (Sugiyono 2013:142). Tes berupa serentetan pertanyaan, lembar kerja atau sejenisnya digunakan untuk mengukur pengetahuan, keterampilan dan bakat kemampuan dari subjek penelitian (Trianto: 2010:264) dan observasi sebagai pengamatan dan pencatatan secara sistematis terhadap gejala yang tampak (Margono, 2005:158). Wawancara untuk memperoleh informasi secara langsung kepada nara sumber (Suharsimi Arikunto, 2010:198). Analisis data dalam penelitian ini dilakukan secara komparatif yaitu memaparkan hasil pengembangan mengenai off job training tentang repair welding dengan tujuan untuk mengetahui perbedaan kemampuan repair welding peserta didik berdasarkan instrumen pelatihan.

Data yang telah didapat melalui angket berupa nilai kualitatif diubah menjadi nilai kuantitatif ditunjukkan pada Tabel 1.

Tabel 1. Aturan Pemberian Skor

\begin{tabular}{lc}
\hline Keterangan & Skor \\
\hline Sangat Setuju & 5 \\
Setuju & 4 \\
Kurang Setuju & 3 \\
Tidak Setuju & 2 \\
Sangat Tidak Setuju & 1 \\
\hline
\end{tabular}

Kemudian data yang terkumpul dianalisis dengan cara menghitung rata-rata. Rata-rata penilaian yang diperoleh dikonversi kembali menjadi kategori kelayakan modul sehingga dapat diambil kesimpulan mengenai kelayakan modul berdasarkan pedoman konversi ideal yang ditunjukkan pada Tabel 2.

Tabel 2. Pedoman Konversi skor

\begin{tabular}{ccc}
\hline No & \multicolumn{1}{c}{ Rumus } & Kategori \\
\hline 1. & $\mathrm{X}>\overline{X_{i}}+1,8 \mathrm{SB}_{\mathrm{i}}$ & Sangat Layak \\
2. & $\overline{X_{i}}+0,6 \mathrm{SB}_{\mathrm{i}}<\mathrm{X} \leq \overline{X_{i}}+1,8 \mathrm{SB}_{\mathrm{i}}$ & Layak \\
3. & $\overline{X_{i}}-0,6 \mathrm{SB}_{\mathrm{i}}<\mathrm{X} \leq \overline{X_{i}}+0,6 \mathrm{SB}_{\mathrm{i}}$ & Cukup Layak \\
4. & $\overline{X_{i}}-0,6 \mathrm{SB}_{\mathrm{i}}<\mathrm{X} \leq \overline{X_{i}}-0,6 \mathrm{SB}_{\mathrm{i}}$ & Kurang Layak \\
5. & $\mathrm{X} \geq \overline{X_{i}}-1,8 \mathrm{SB}_{\mathrm{i}}$ & Sangat Kurang \\
& & Layak \\
\hline
\end{tabular}

Data hasil belajar (pre-test dan post-test) selanjutnya dianalisis dengan menggunakan gain-test. Teknik analisis data gain-test adalah dengan menghitung nilai gain ( $g$ ) dengan persamaan 1 .

$g=\frac{\text { Skor Posttest-Skor Pretest }}{\text { Skor Maksimum-Skor Pretest }}$

Pengukuran efektivitas dari penelitian ini digunakan uji non parametrik yang merupakan statistik parameter yang digunakan untuk menguji hipotesis, komparatif rata-rata dua sampel. Uji Non-parametrik yang digunakan untuk hipotesa ini adalah uji Wilcoxon. Pengujian ini dilakukan untuk membandingkan antara dua kelompok data yang saling berhubungan (Sugiyono 2013:134-142). Dasar pengambilan keputusan dalam uji Wilcoxon yaitu Ho adalah tidak ada perbedaan nilai pretest dan post-test pada peserta didik menggunakan model pembelajaran off job training dan Ha adalah ada perbedaan nilai pretest dan post-test pada peserta didik menggunakan model pembelajaran off job training.

\section{HASIL DAN PEMBAHASAN}

Observasi dilakukan di lokasi proyek difokuskan pada obyek komponen alat berat jenis excavator. Hasil observasi menunjukkan bahwa pada salah satu komponen excavator yaitu boom sering mengalami kerusakan. Hasil inspeksi secara visual menunjukkan bahwa pada boom excavator Hitachi 3300 terjadi cacat pada bagian sisi-sisi pinggir sambungan las. 
Pengamatan juga dilakukan dengan menggunakan non destructive test, dimana hasilnya juga menunjukkan adanya retakan yang terjadi pada permukaan luar boom.

Pengumpulan data juga dilakukan secara wawancara terhadap para trainer serta mekanik di lokasi proyek yang berkaitan dengan cacat pada boom excavator tersebut. Wawancara ini dilakukan terhadap specialist trainer welding, diperoleh informasi bahwa alat berat jenis excavator merupakan kunci utama peningkatan produktivitas pekerjaan di tambang, sehingga alat tersebut harus dalam kondisi optimal dan selalu siap untuk digunakan. Hasil wawancara ini juga menunjukkan bahwa pihak job site mengeluhkan komponen boom excavator (lengan) yang sering mengalami cacat berupa crack (retakan). Berdasarkan hasil dari ultrasonic inspection report Hitachi backhoe, diketahui bahwa mekanik hanya memiliki kompetensi dasar perbaikan pada cacat yang dialami alat berat secara umum, sedangan pihak Training Centre PT Thiess belum memiliki training package mengenai kompetensi perbaikan hasil lasan.

Hasil observasi dan wawancara tersebut kemudian digunakan sebagai bahan penyusunan desain training package, yang merupakan hasil dari analisis yang akan dikonsepkan dalam sebuah kerangka-kerangka training package. Hasil analisis permasalahan dibuat draft kurikulum dalam bentuk training catalogue yang nantinya akan dijadikan acuan untuk membuat perangkat pendudukung pelatihan. Semua perangkat pelatihan tersebut dibuat dalam sebuah kerangka artinya masih berupa poin-poin pokok yang harus dikembangkan untuk meningkatkan pengetahuan dan keterampilan mengenai perbaikan hasil lasan pada boom excavator. Poin pokok tersebut diantaranya adalah proses inspeksi boom, membuat penahan boom atau biasa dikenal dengan istilah restraining, melakukan proses gouging dan grinding, serta preheating dan repair welding.

Langkah selanjutnya adalah melakukan pengembangan terhadap draft training package yang sudah disusun tersebut. Pengembangan training package berdasarkan desain yang telah terbentuk berupa kerangka produk dijabarkan dalam lingkup yang lebih luas. Penjabaran ini didasarkan dari kurikulum pelatihan yang telah dibuat. Kurikulum harus memiliki perangkat pendukung meliputi module descriptor, lesson plan, hand out training, media pelatihan serta portofolio assessment. Jika semua perangkat ini sudah terbentuk maka sudah jadi sebuah training package, namun training package ini masih perlu divalidasi oleh para trainer welding. Validasi produk merupakan tahapan pengembangan yang dilakukan untuk mengetahui kelayakan media yang telah dibuat sebelum diimplementasikan pada peserta didik.

Implementasi training package ini dilaksanakan pada apprentice program group XXI welder dengan jumlah peserta didik sebanyak 10 orang. Implementasi dilaksanakan dengan memberikan pre-test dan post-test, sehingga dapat dijadikan sebagai penilaian terhadap training package. Hasil pre-test dan post-test pada saat implementasi diperoleh nilai rata-rata hasil pre-test yang ditunjukkan pada Tabel 3 dan Tabel 4.

Tabel 3. Nilai Rata-rata Pre-Test

\begin{tabular}{ccccc}
\hline No & Interval & $\mathrm{x}_{1}$ & Frekuensi $\left(\mathrm{f}_{1}\right)$ & $\mathrm{f}_{1} \mathrm{x}_{1}$ \\
\hline 1 & $75-79$ & 77 & 2 & 154 \\
2 & $80-84$ & 82 & 3 & 246 \\
3 & $85-89$ & 87 & 1 & 87 \\
4 & $90-94$ & 92 & 4 & 368 \\
\hline \multicolumn{3}{c}{ Jumlah } & 10 & 855 \\
\hline \multicolumn{3}{c}{ Rata-rata $=\frac{\sum f 1 \times 1}{\sum f 1}$} & $\mathbf{8 5 . 5}$ \\
\hline
\end{tabular}

Tabel 4. Nilai Rata-rata Post-Test

\begin{tabular}{ccccc}
\hline No & Interval & $\mathbf{x}_{\mathbf{1}}$ & Frekuensi $\left(\mathbf{f}_{\mathbf{1}}\right)$ & $\mathbf{f}_{\mathbf{1}} \mathbf{x}_{\mathbf{1}}$ \\
\hline 1 & $89-91$ & 90 & 3 & 270 \\
2 & $92-94$ & 93 & 3 & 279 \\
3 & $95-97$ & 96 & 3 & 288 \\
4 & $98-100$ & 99 & 1 & 99 \\
\hline \multicolumn{7}{r}{ Jumlah } & 10 & 936 \\
\hline
\end{tabular}

$$
\text { Rata-rata }=\frac{\sum f 1 x 1}{\sum f 1} \quad \mathbf{9 3 , 6}
$$

Nilai rata-rata pre-test dan post-test kemudian dianalisis menggunakan gain-test 
sehingga diperoleh nilai 0,56 . Nilai tersebut masuk dalam interpretasi sedang, sehingga dapat disimpulkan bahwa ada peningkatan hasil pelatihan repair welding dengan model pembelajaran off job training pada peserta didik termasuk dalam interpretasi sedang. Hasil perhitungan peningkatan belajar para peserta didik ditunjukkan pada Gambar 1.

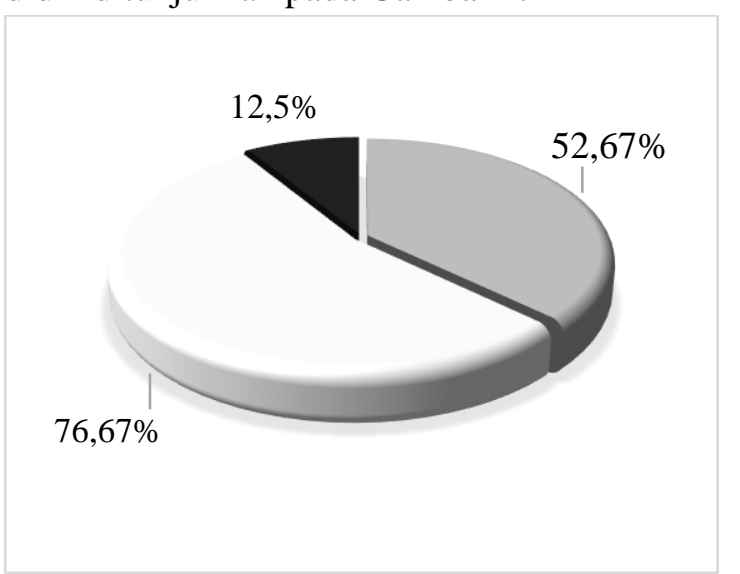

Gambar 1. Diagram Kategori Peningkatan Kemampuan Peserta Didik

Evaluasi dilakukan untuk mengetahui kekurangan training package yang telah dibuat dengan menganalisis portofolio assessment serta melakukan wawancara terhadap peserta didik setelah mengikuti pelatihan. Saran dan masukan yang didapat melalui wawancara tersebut dijadikan sebagai bahan pertimbangan untuk perbaikan training package.

Berdasarkan pembahasan di atas maka karakteristik dari pembelajaran off job training repair welding boom excavator meliputi: pembelajaran yang dilakukan berdasarkan studi kasus yang ada di lokasi kerja, peserta pelatihan terbatas dengan tujuan memaksimalkan hasil pelatihan, metode yang digunakan berupa group teaching, peserta didik bersifat aktif terhadap proses pelaksanaan pelatihan, proses pembelajaran yang dilakukan menggunakan simulasi sesuai permasalahan.

Training Package dan media pendukung yang dikembangkan harus divalidasi untuk mengetahui keefektifannya dengan beberapa aspek penilaian oleh spesialis trainer welding. Berdasarkan hasil validasi ahli materi diperoleh rata-rata sebesar 4,06 yang termasuk dalam kategori layak. Hasil validasi ahli materi yang ditunjukkan dalam Gambar 2.

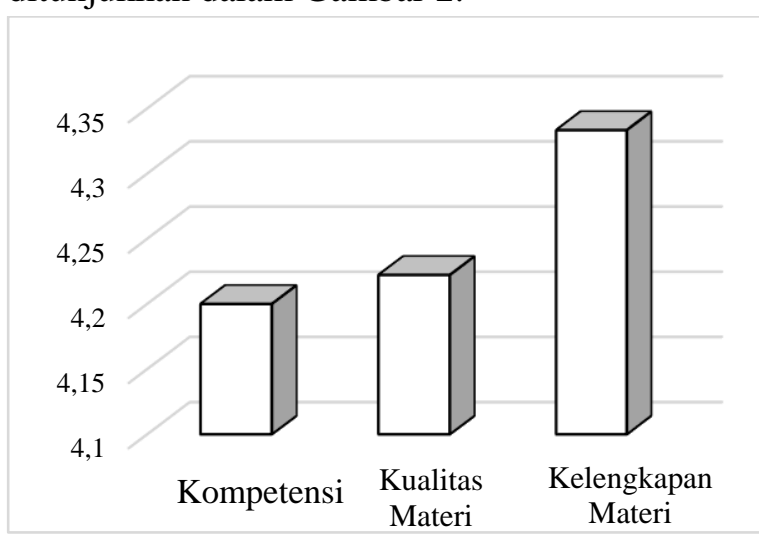

Gambar 2. Diagram Validasi Spesialis Training Welding

Trainer sebagai pelaksana pembelajaran di lapangan juga memberikan penilaian terhadap model pembelajaran ini dengan mengisi angket lembar penilaian untuk trainer. Berdasarkan hasil validasi oleh trainer diperoleh rata-rata sebesar 4,24 yang termasuk dalam kategori sangat layak. Hasil validasi oleh trainer disajikan dalam diagram batang seperti Gambar 3. Secara keseluruhan media yang dikembangkan layak digunakan dan siap dilakukan proses implementasi pada peserta pelatihan.

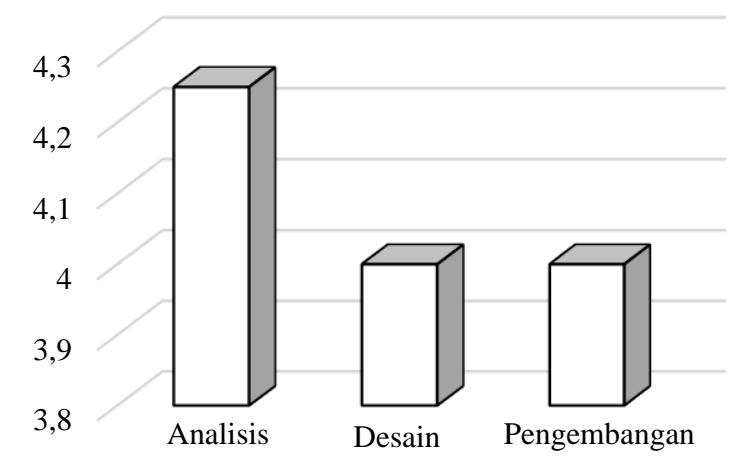

Gambar 3. Diagram Validasi Trainer Officer Welding

Pengukuran efektivitas pembelajaran off job training dilakukan saat implementasi produk, yaitu peserta didik diberikan soal pretest dan post-test pada saat sebelum dan sesudah menggunakan training package 
sebagai model pembelajaran. Data utama yang dipakai untuk melihat hasil peningkatan pelatihan repair welding menggunakan model pengembangan pembelajaran off job training adalah nilai hasil pre-test dan post-test. Sebelum dilakukan uji hipotesis, terlebih dahulu dilakukan uji normalitas distribusi data dan homogenitas varians data kedua kelompok. Uji normalitas bertujuan untuk menguji data penelitian yang dilakukan memiliki distribusi yang normal atau tidak. Uji normalitas pada penelitian ini menggunakan Shapiro-Wilk pada program SPSS versi 23.0 yang ditunjukkan pada Tabel 5.

Tabel 5. Hasil Uji Normalitas Nilai Pre-test dan Post-test Peserta Didik

\begin{tabular}{ccccccc}
\hline \multirow{3}{*}{ Grup } & \multicolumn{3}{c}{ Kolmogorov- } & \multicolumn{3}{c}{ Shapiro-Wilk } \\
& Statistic & df & Sig. & Statistic & df & Sig. \\
\hline Pretest & 0,229 & 10 &, 147 & 0,898 & 10 &, 211 \\
Postest & 0,255 & 10 &, 064 & 0,946 & 10 &, 618 \\
\hline
\end{tabular}

Berdasarkan hasil uji normalitas ShapiroWilk di atas, menunjukkan bahwa nilai signifikan pada kelompok pre-test sebesar $0.211>0.05$ dan nilai signifikan kelompok posttest sebesar $0.618>0.05$, sehingga dapat disimpulkan bahwa data yang diuji merupakan data dengan distribusi normal

Uji homogenitas digunakan untuk mengetahui varian dari beberapa populasi sama atau tidak. Uji homogenitas pada penelitian ini menggunakan Levene Test. Hasil uji homogenitas Levene Test nilai pre-test dan post-test peserta didik ditunjukkan pada Tabel 6.

Tabel 6. Hasil Uji Homogenitas Nilai Pre-test dan Post-Test Peserta Didik

\begin{tabular}{lrccl}
\hline & Levene & $\mathrm{df}_{1}$ & $\mathrm{df}_{2}$ & Sig. \\
\hline Mean & 6,418 & 1 & 18 & 0,021 \\
Median & 6,266 & 1 & 18 & 0,022 \\
Median and with & 6,266 & 1 & 18,000 & 0,022 \\
adjusted df & & & 18 & 0,021 \\
Trimmed mean & 6,418 & 1 & 18 \\
\hline
\end{tabular}

Berdasarkan hasil uji homogenitas Levene Test pada tabel di atas menunjukkan bahwa uji homogenitas nilai Based on trimmed mean adalah 0.021 dengan taraf kepercayaan
0.05. Hasil nilai mean sebesar $0.021<0.05$, sehingga dapat disimpulkan bahwa data nilai pre-test dan post test pada peserta didik berasal dari varian yang tidak homogen.

Uji non-parametrik dilakukan bila data diketahui normal tetapi tidak homogen maka dapat diambil keputusan untuk melakukan uji hipotesis wilcoxon, karena data yang diperoleh saling berhubungan (Jumiati, dkk, 2011). Hasil uji non-parametrik Wilcoxon pada nilai pre-test dan post-test peserta didik ditunjukkan pada Tabel 7.

Tabel 7. Hasil Uji Non-Parametrik Wilcoxon Nilai Pre-test dan Post-Test Peserta Didik

\begin{tabular}{lc} 
& Post-Test-Pre-Test \\
\hline $\mathrm{Z}$ & $-2,705^{\mathrm{b}}$ \\
Asymp. Sig. (2-tailed) & 0,007 \\
\hline
\end{tabular}

Hasil uji non-parametrik Wilcoxon pada tabel di atas, menunjukkan bahwa nilai Sig. (2tailed) diperoleh $p$-value sebesar 0.007. Dari hasil di atas, dapat disimpulkan bahwa 0,007 < 0,05 tolak $\mathrm{H}_{0}$ yang menyatakan bahwa ada perbedaan nilai pre-test dan post-test peserta didik dengan model pengembangan pembelajaran Off Job Training.

\section{SIMPULAN}

Simpulan hasil penelitian ini menunjukkan bahwa karakteristik pembelajaran off job training berupa peserta pelatihan terbatas dengan pembelajaran berupa group teaching dimana pesera didik bersifat aktif dengan menggunakan metode simulasi saat proses pembelajaran. Efektifitas pembelajaran berdasarkan uji non-parametrik wilcoxon menunjukkan bahwa nilai Sig. (2-tailed) untuk data nilai pre-test dan post-test peserta didik adalah 0.007 dengan nilai signifikan 0,007 < 0,05 , artinya tolak $\mathrm{H}_{0}$ yang menyatakan bahwa ada perbedaan nilai pre-test dan post-test peserta didik dengan model pengembangan pembelajaran Off Job Training.

Hasil penelitian ini diharapkan dapat digunakan untuk mengembangkan model pembelajaran lain diantaranya model 
pembelajaran on job training atau juga dapat dijadikan sebagai acuan untuk membandingkan model pembelajaran yang lebih efektif.

\section{DAFTAR RUJUKAN}

Akhmad Sudrajat. (2010). Model Pembelajaran Afektif dan Sikap. Diakses pada tanggal $10 \quad$ Juli $2014 \quad$ dari http://akhmadsudrajat/modelpembelajaran-afektif-sikap/.

Benny A. Pribadi. (2009). Model Desain Sistem Pembelajaran. Jakarta: Dian Rakyat.

Dodi Arifandi. (2012). Exper Thiess Vol. 2. Diakses pada tanggal 10 Juli 2014 dari http://thiess.co.id/files/documents/expert hiess-02-2012-eng-low.pdf

Jumiati, et all. (2011). Peningkatan Hasil Belajar Siswa dengan Menggunakan Model Numbereds Heads Together (NHT) pada Materi Gerak Tumbuhan di Kelas VIII SMP Sei Putih Kampar. Jurnal Lectura (Vol. 2, Nomor 2, Agustus 2011). Hlm. 161-185.
Margono. (2005). Metodologi Penelitian Pendidikan. Jakarta: Rineka Cipta.

Sri Rahayu. (2014). Undang-Undang No 20 Tahun 2003 Tentang Sistem Pendidikan Nasional. Diakses pada tanggal 5 Juli 2014 dari http://www.komnasham.go.id/instrumenham-nasional/uu-no-20-tahun-2003tentang-sistem-pendidikan-nasional/

Sugiyono. (2013). Metode Penelitian Pendidikan (Penelitian Kuantitatif, Kualitatatif) dan $R$ \& $D$. Bandung: Alfabeta.

Suharsimi Arikunto. (2010). Prosedur Penelitian Suatu Pendekatan Praktik. Jakarta: PT. Rineka Cipta.

Trianto. (2010). Mengembangkan Model Pembelajaran Tematik. Jakarta: PT Prestasi Pustaka. 